\title{
PERANCANGAN SISTEM INFORMASI PENDIDIKAN DAN PELATIHAN (DIKLAT) DI BALAI BESAR PELATIHAN KESEHATAN CILOTO
}

\author{
Lila Setiyani, ST., M.Kom \\ E-mail : lila.jatayu.ck@gmail.com
}

\begin{abstract}
ABSTRAKSI
Balai Besar Pelatihan Kesehatan (BBPK) Ciloto yang mempunyai tugas pokok melaksanakan pendidikan dan pelatihan (diklat) serta pengembangan sumber daya manusia kesehatan masyarakat. Dalam pengelolaan diklat BBPK Ciloto sering mengalami kesulitan dalam proses administrasi registrasi pelatihan. Pengelolaan yang ada sekarang menggunakan website namun pengolahan datanya dilakukan dengan microsoft office excel , untuk komunikasi antar unit kerja masih menggunakan manual yaitu menggunakan email. Untuk itu dibutuhkan suatu sistem informasi yang dapat terintegrasi antar unit kerja di BBPK Ciloto sehingga proses pengolahan data dan komunikasi antar unit kerja dapat dilakukan dengam mudah dan terdokumentasi dengan baik. Permasalahan tersebut melatarbelakangi peneliti untuk mengembangkan sistem informasi diklat berbasis web. Dalam proses pengembangan sistem, peneliti menggunakan metode waterfall dan php. Hasil penelitian ini adalah sebuah sistem informasi yang dapat mengelola diklat dan kemudahan komunikasi antar unit kerja BBPK Ciloto. Berdasarkan hasil pengujian, menurut pengguna sistem informasi diklat ini cukup memberikan manfaat dan solusi dari permasalahan yang ada.

Kata Kunci : sistem informasi, diklat, web, waterfall
\end{abstract}

\begin{abstract}
Health Training Center (BBPK) Ciloto which has the main duty to carry out education and training (training) and human resources public health development. In the management of training BBPK Ciloto often have difficulty in the administrative process of registration training. Current management using website but its data processing is done by microsoft office excel, for communication between work unit still use manual that is using email. For that we need an information system that can be integrated between work units in BBPK Ciloto so that data processing and communication between work units can be done with easy and well documented. The problem is behind the researchers to develop web-based information management system. In the process of system development, researchers use waterfall and php methods. The results of this study is an information system that can manage the training and ease of communication between work units $B B P K$ Ciloto. Based on the test results, according to users of this training information system is enough to provide benefits and solutions of existing problems.
\end{abstract}

Keywords : Information System, Eduacation and Training, web, waterfall 


\section{PENDAHULUAN}

BBPK Ciloto adalah unit pelaksana teknis di lingkungan Kementerian RI yang berada dibawah naungan Badan Pengembangan dan Pemberdayaan SDM Kesehatan, dan dalam melaksanakan teknis dan fungsionalnya dibina oleh Pusdiklat Aparatur dan Pusdiklat Tenaga Kesehatan. Tugas pokok dari BBPK Ciloto adalah melaksanakan pendidikan dan pelatihan serta pengembangan sumber daya manusia kesehatan masyarakat.

BBPK Ciloto membuka pelatihan dan jenis pelatihan di tampilkan di kalender pelatihan website BBPK Ciloto. Untuk dapat mengikuti pelatihan peserta harus melakukan registrasi melalui website BBPK Ciloto setelah itu peserta akan mendapatkan konfirmasi melalui telepon atau email dari pihak BBPK Ciloto.

Proses registrasi diklat di BBPK Ciloto walupun berbasis website namun peserta tidak dapat melihat progres pendaftarannya , sehingga peserta kesulitan dalam melihat tanggapan dari pihak BBPK.

Unit kerja di BBPK Ciloto yang berkaitan dengan pengelolaan pelatihan adalah unit P3. Unit ini mengolah dari proses registrasi, seleksi peserta, penyelenggaraan diklat, penunjukan fasilitator, proses evaluasi dan proses pembuatan sertifikat.

Unit kerja di BBPK Ciloto yang mensupport terkait dana adalah unit keuangan. Unit keuangan mendapatkan informasi terkait jumlah peserta dan biaya penyelenggaraan dari unit P3. Dan dalam pengelolaan registrasi sampai dalam pembuatan jadwal dan pembuatan sertifikat manajemen BBPK Ciloto masih menggunakan cara komunikasi manual, belum menggunakan sebuah sistem. Sehingga dalam pemantaunnya prosentase sebuah pelatihan yang selenggarakan pun sulit untuk di ukur. Terutama dari unit keuangan kesulitan dalam menyiapkan dana untuk proses penyelenggaran diklat karena kurang mendapatkan informasi.

Penjabaran permasalahan yang ada terkait proses pengelolaan diklat maka dalam penelitian ini akam membangun sistem informasi diklat yang ditujukan untuk BBPK Ciloto yang terintegrasi antar unit P3 dengan keuangan. Untuk proses pengembangannya sistem informasi diklat ini menggunakan bahasa pemograman PHP dengan framework CodeIgneter. Dengan metode waterfall sebagai meteode dalam pengembangan sistem yang dilakukan pada penelitian ini.

\section{TINJAUAN PUSTAKA}

\section{PHP Framework Code Igniter}

PHP adalah singkatan dari PHP Hypertext Prepocessor yaitu bahasa pemograman yang digunakan dalam pembuatan dan pengembangan sebuah aplikasi web dan penggunaanya biasanya digunakan bersamaan dengan HTML.

Mengutip dari tutorialspoint.com (update 2018), "CodeIgniter is a powerful PHP framework with a very small footprint, built for developers who need a simple and elegant toolkit to create full-featured web applications".

\section{Flowchart}

Menurut Andika (2018), "Flowchart adalah bagan-bagan yang memunyai arus yang menggabarkan langkah-langkah penyelesaian suatu masalah".

\section{Metode Waterfall}

Menurut Pressman (2015:42), "model waterfall adalah model klasik yang bersifat sistematis, berurutan dalam membangun software". Nama model ini sebenarnya adalah "Linear Sequential Model". Model ini sering disebut juga dengan "classic life cycle" atau metode waterfall. Model ini termasuk ke dalam model generic pada rekayasa perangkat lunak dan pertama kali diperkenalkan oleh Winston Royce sekitar tahun 1970 sehingga sering dianggap kuno, tetapi merupakan model yang paling banyak dipakai dalam Software Engineering (SE).

Model ini melakukan pendekatan secara sistematis dan berurutan. Disebut dengan waterfall karena tahap demi tahap yang dilalui harus menunggu selesainya tahap sebelumnya dan berjalan berurutan.

Fase-fase dalam Waterfall Model menurut referensi Pressman : 


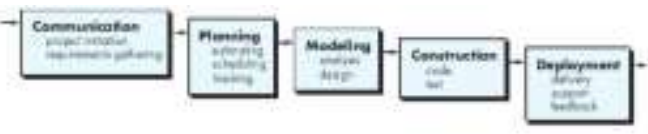

Gambar 1. Waterfall Pressman (Pressman, 2015:42)

Communication (Project Initiation \& Requirements Gathering) Sebelum memulai pekerjaan yang bersifat teknis, sangat diperlukan adanya komunikasi dengan customer demi memahami dan mencapai tujuan yang ingin dicapai. Hasil dari komunikasi tersebut adalah inisialisasi proyek, seperti menganalisis permasalahan yang dihadapi dan mengumpulkan data-data yang diperlukan, serta membantu mendefinisikan fitur dan fungsi software. Pengumpulan datadata tambahan bisa juga diambil dari jurnal, artikel, dan internet.

Planning (Estimating, Scheduling, Tracking) Tahap berikutnya adalah tahapan perencanaan yang menjelaskan tentang estimasi tugas-tugas teknis yang akan dilakukan, resiko- resiko yang dapat terjadi, sumber daya yang diperlukan dalam membuat sistem, produk kerja yang ingin dihasilkan, penjadwalan kerja yang akan dilaksanakan, dan tracking proses pengerjaan sistem.

Modeling (Analysis \& Design) Tahapan ini adalah tahap perancangan dan permodelan arsitektur sistem yang berfokus pada perancangan struktur data, arsitektur software, tampilan interface, dan algoritma program. Tujuannya untuk lebih memahami gambaran besar dari apa yang akan dikerjakan.

Construction (Code \& Test) Tahapan Construction ini merupakan proses penerjemahan bentuk desain menjadi kode atau bentuk/bahasa yang dapat dibaca oleh mesin. Setelah pengkodean selesai, dilakukan pengujian terhadap sistem dan juga kode yang sudah dibuat. Tujuannya untuk menemukan kesalahan yang mungkin terjadi untuk nantinya diperbaiki.

Deployment (Delivery, Support, Feedback) Tahapan Deployment merupakan tahapan implementasi software ke customer, pemeliharaan software secara berkala, perbaikan software, evaluasi software, dan pengembangan software berdasarkan umpan balik yang diberikan agar sistem dapat tetap berjalan dan berkembang sesuai dengan fungsinya.

\section{Unified Modeling Language}

Menurut Whitten \& Bentley (2004:371), "Unified Modeling Language (UML) versi 2.0 adalah sekumpulan konversi pemodelan yang digunakan untuk menentukan atau menggambarkan sebuah sistem software yang terkait dengan objek".

Menurut Whitten dan Bentley (2004:382), "UML menyediakan tiga belas macam diagram untuk memodelkan aplikasi berorientasi objek, yaitu:

- Use Case Diagram menggambarkan interaksi Antara system internal, sistem eksternal, dan user.

- Activity Diagram menggambarkan alur sequential dari aktivitas sebuah proses bisnis atau Use Case.

- Class Diagram menggambarkan struktur objek sistem. Menunjukkan kelas yang menjadi komponen dari sistem, serta hubungan antar kelas.

- Object Diagram serupa dengan Class Diagram, memodelkan instansi objek yang sebenarnya beserta nilai atributnya.

- State Machine Diagram untuk memodelkan perilaku objek di dalam sistem terhadap kejadian (event) selama masa hidupnya.

- Composite Structure Diagram menguraikan struktur internal, komponen, atau Use Case dari suatu kelas.

- Sequence Diagram menggambarkan bagaimana objek berinteraksi melalui pengiriman pesan (message) dalam pengeksekusian sebuah Use Case atau operasi tertentu.

- Communication Diagram disebut juga Collaboration Diagram mirip dengan Sequence Diagram. Namun, Sequence Diagram lebih berfokus pada pemilihan waktu atau urutan pesan. Communication Diagram berfokus pada penyusunan struktur objek dalam bentuk jaringan.

- Interaction Overview Diagram mengkombinasikan Activity Diagram dengan Sequence Diagram untuk 
menunjukkan bagaimana objek berinteraksi dalam tiap aktivitas Use Case.

- Timing Diagram adalah diagram interaksi lain yang berfokus pada batasan pemilihan waktu dalam keadaan satu objek atau kumpulan objek yang berubah. Diagram ini sangat berguna ketika mendesain embedded software untuk banyak perangkat.

- Component Diagram menggambarkan penyusunan kode programming yang dibagi menjadi beberapa komponen dan menjelaskan bagaimana komponen tersebut berinteraksi.

- Deployment Diagram menggambarkan konfigurasi dari komponen software dalam arsitektur fisik dari "simpul - simpul" sistem hardware.

- Package Diagram menggambarkan bagaimana kelas/konstruksi dari UML lain disusun dalam bentuk paket (berkaitan dengan paket Java atau $C++$ dan namespaces dari .NET) dan ketergantungannya antar paket.

\section{METODE PENELITIAN}

\section{Model Penelitian}

Penelitian ini terdiri dari 3 (tiga) komponen yaitu input, proces dan output. Pada komponen input terdiri dari data-data yang menjadi masukan dalam pengembangan peneltian yaitu membangun Sistem Informasi Diklat. Pada komponen process adalah penggambaran aktivitas dari Sistem Informasi Diklat atau desain yang akan dikembangkan berdasarkan hasil analisis data. Input dari penelitian ini adalah konsep pengelolaan diklat hasil dari studi pustaka yang dilakukan dalam penelitian. Kemudian proses bisnis dari pengelolaan diklat yang disertai dengan dokumen-dokumen terkait seperti perencanaan diklat, penyelenggaraan diklat dan evaluasi diklat. Process merupakan desain dari kegiatan sistem informasi diklat yang akan dibangun. Dikaitkan dengan metode pengembangan, objek dan data yang akan dikembangkan. Output adalah fitur-fitur dari sistem informasi diklat yang dilengkapi dengan pelaporan.

\section{Tahapan Penelitian}

Tahapan penelitian ini menggabungkan tahapan pada waterfall. Berikut diagram tahapan penelitian :

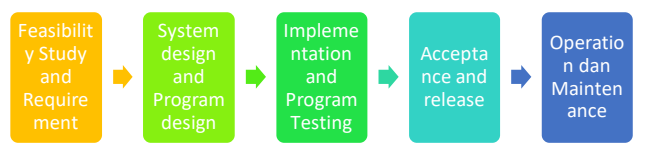

Gambar 2. Tahapan penelitian

Feasibility Study dilakukan untuk mengetahui kesiapan dari segi infrastruktur dan kesiapan sumber daya manusia yang ada di BBPK Ciloto dalam menggunakan Sistem Informasi Diklat ini.

Requirement adalah proses analis mencari tahu dan memahami kebutuhan user.

System design dan program design adalah proses perancangan desain sistem yang tertuang dalam diagram seperti use case diagram, activity diagram, squense diagram dan class diagram sedangkan desain program adalah proses penerjemahan desain ke dalam bahasa pemograman.

Implementation and program testing adalah proses mengimplemntasikan program dan uji aplikasi oleh programer.

Aceptance and release adalah proses uji aplikasi oleh customer yaitu BBPK Ciloto, jika sudah sesuai maka sistem dapat segera di launching, jika belum selesai maka sistem di lakukan perbaikan

Operation and maintenance adalah proses mengoperasikan aplikasi dan melakukan pemeliharaan sistem.

\section{HASIL DAN PEMBAHASAN}

Hasil dari penelitian ini adalah Sistem Informasi Diklat yang memiliki fungsi untuk mengelola kegiatan diklat terkait perencanaan diklat, penyelenggaraan dan evalaluasi diklat, serta pelaporan penyelenggaraan diklat. . Berikut merupakan tampilan hasil dari sistem yang telah di bangun : 


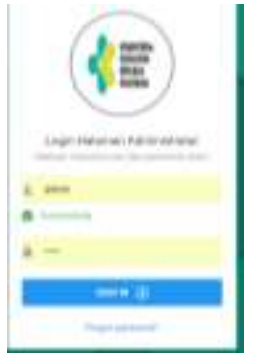

Gambar 3. Tampilan Login untuk user unit kerja BBPK Ciloto

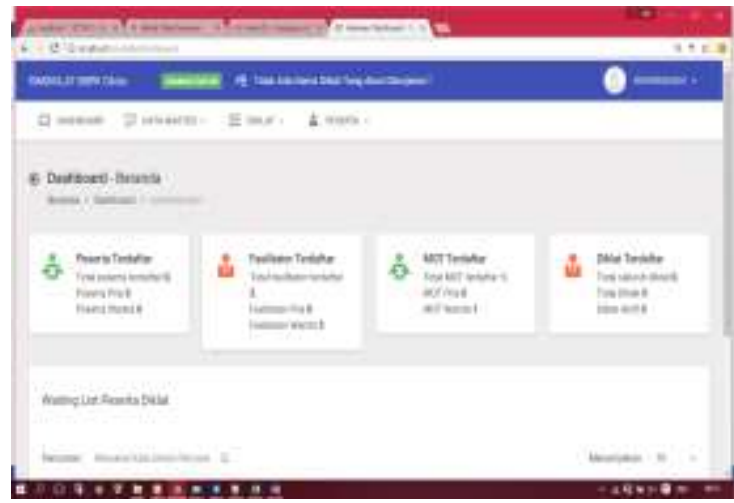

Gambar 4. Tampilan dashboard untuk user admin

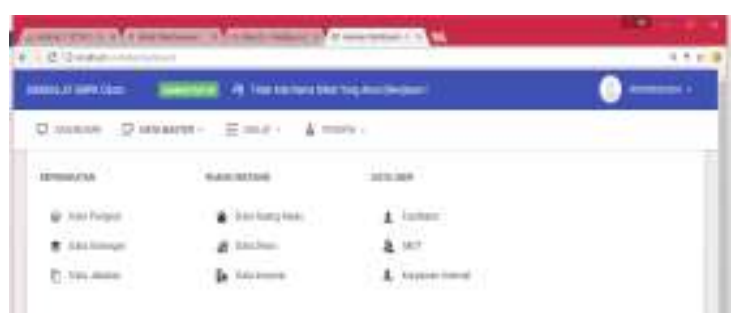

Gambar 5. Tampilan menu untuk pengisian data master

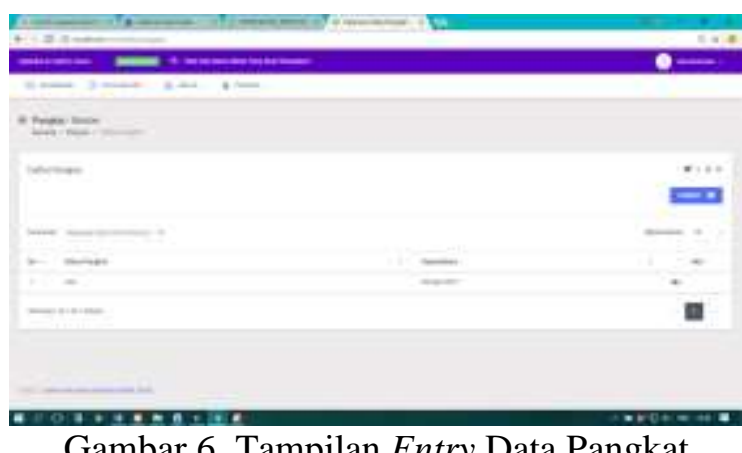

Gambar 6. Tampilan Entry Data Pangkat
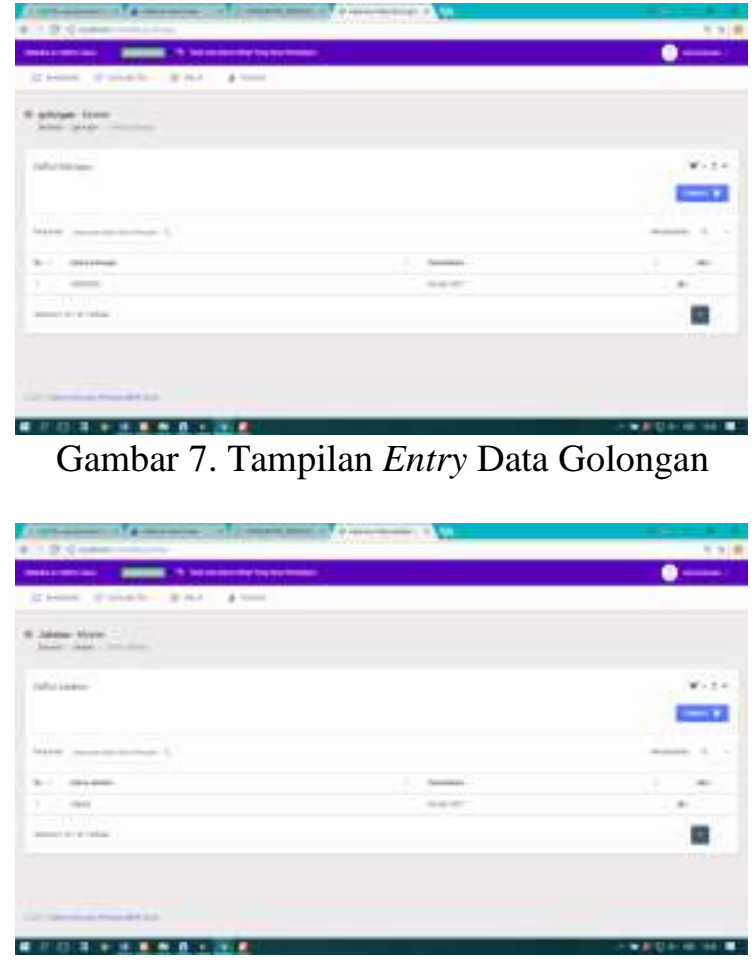

Gambar 8. Tampilan Entry Jabatan

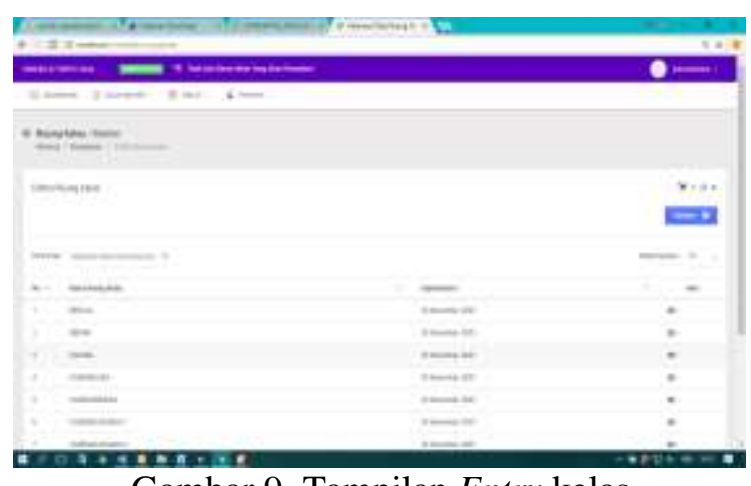

Gambar 9. Tampilan Entry kelas

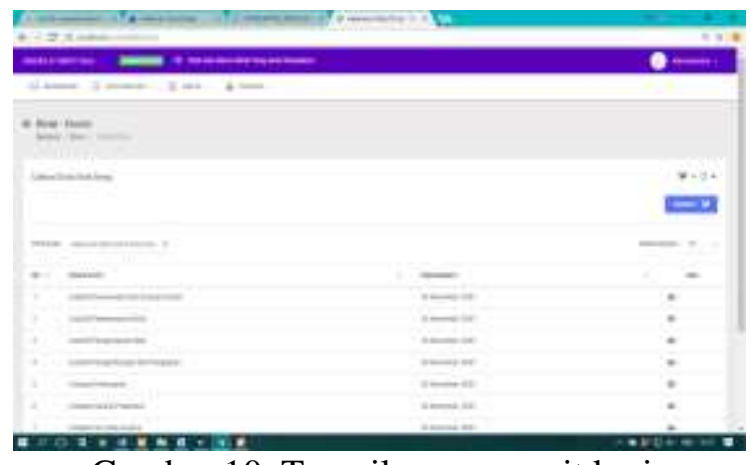

Gambar 10. Tampilan entry unit kerja 


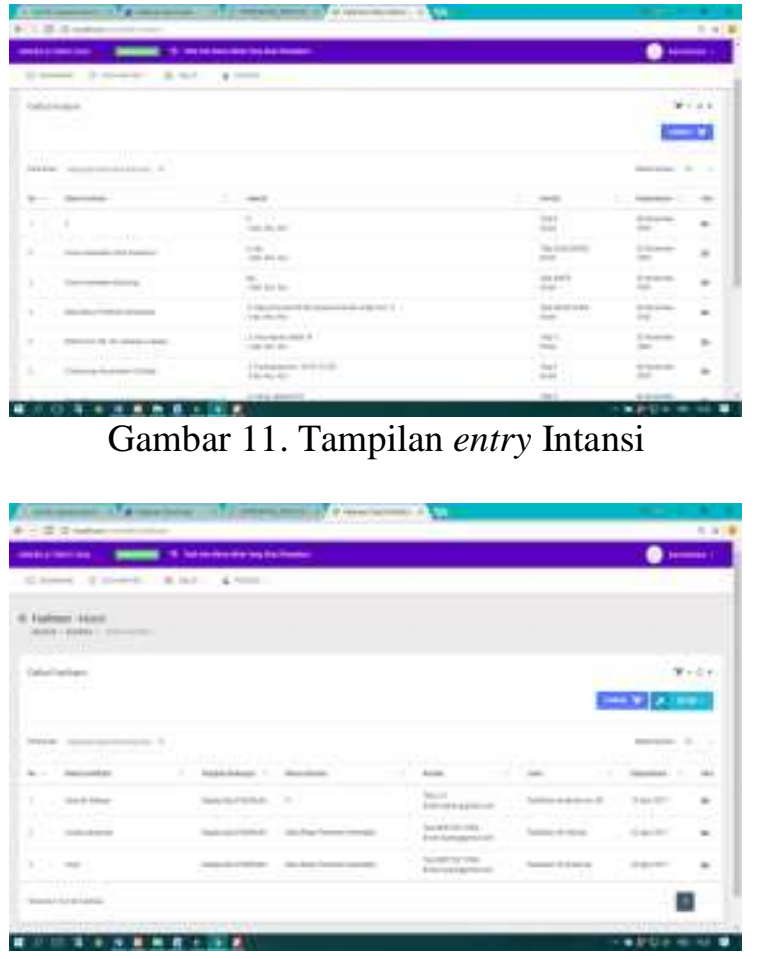

Gambar 12. Tampilan entry fasilitator

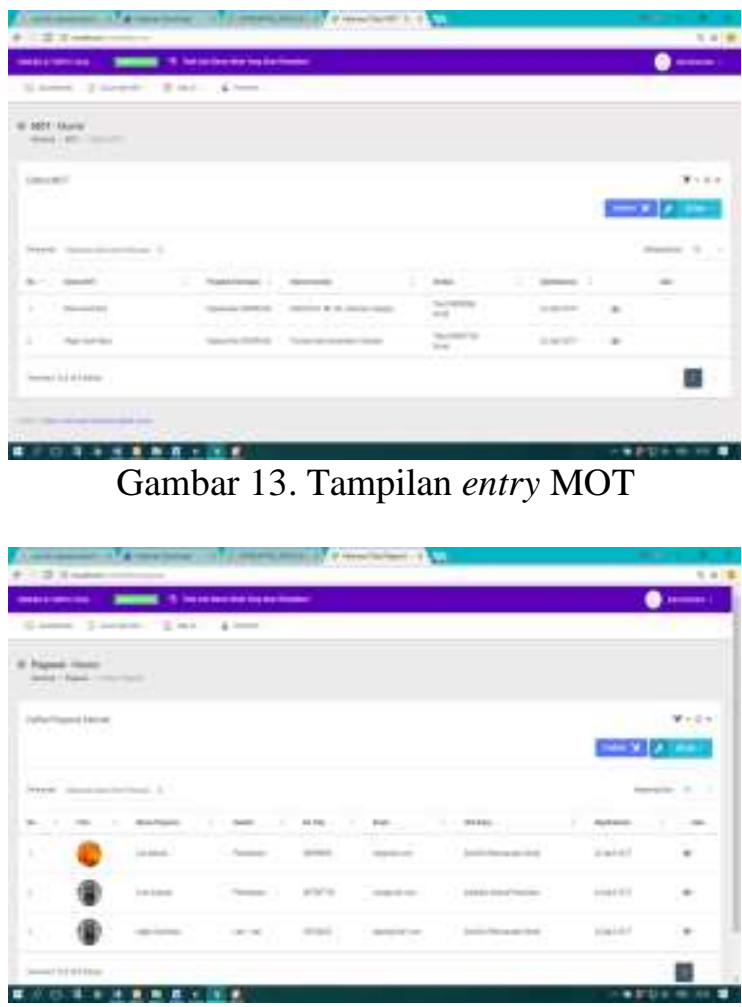

Gambar 14. Tampilan entry karyawan/pegawai

Dashboard ini digunakan untuk pengisian data master.

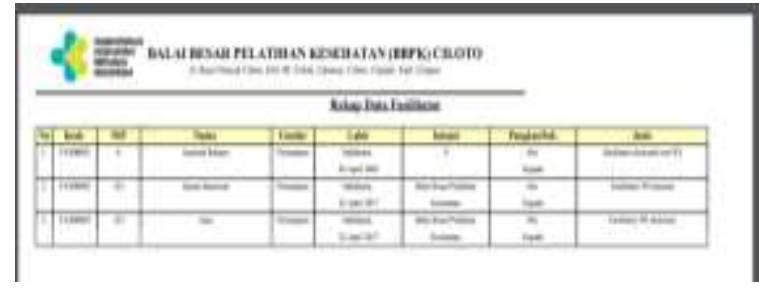

Gambar 15. Tampilan hasil cetak

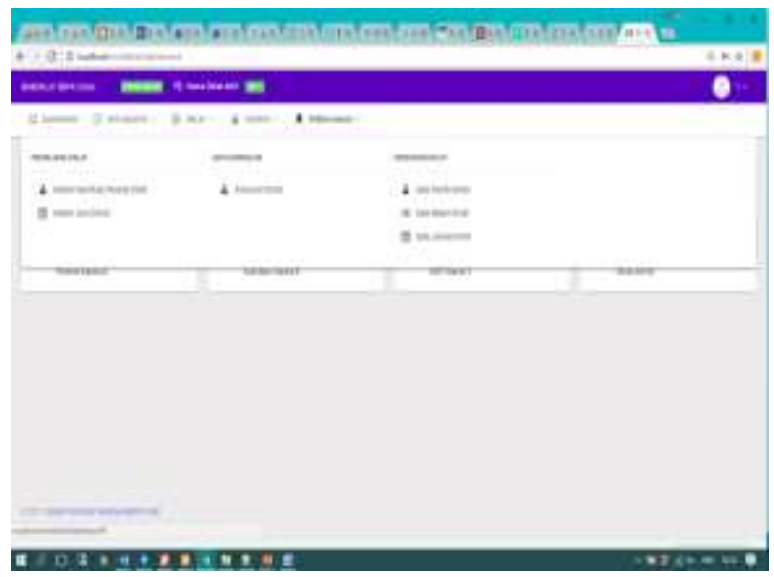

Gambar 16. Tampilan dashboard untuk user perencanaan diklat

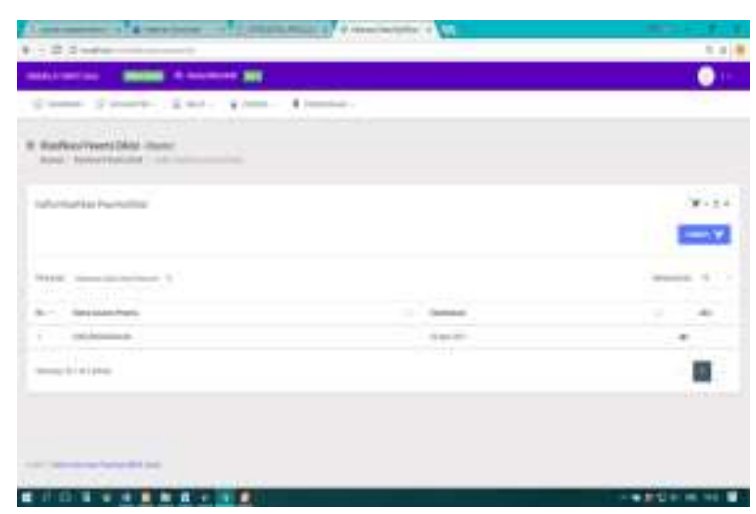

Gambar 17. Tampilan entry klasifikasi peserta diklat

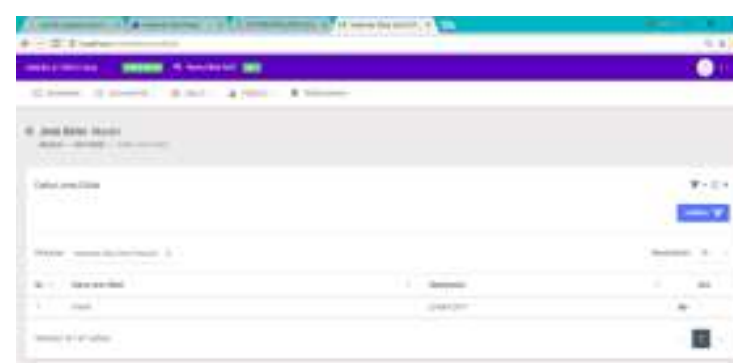

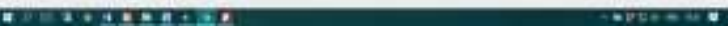

Gambar 18. Tampilan entry jenis diklat 


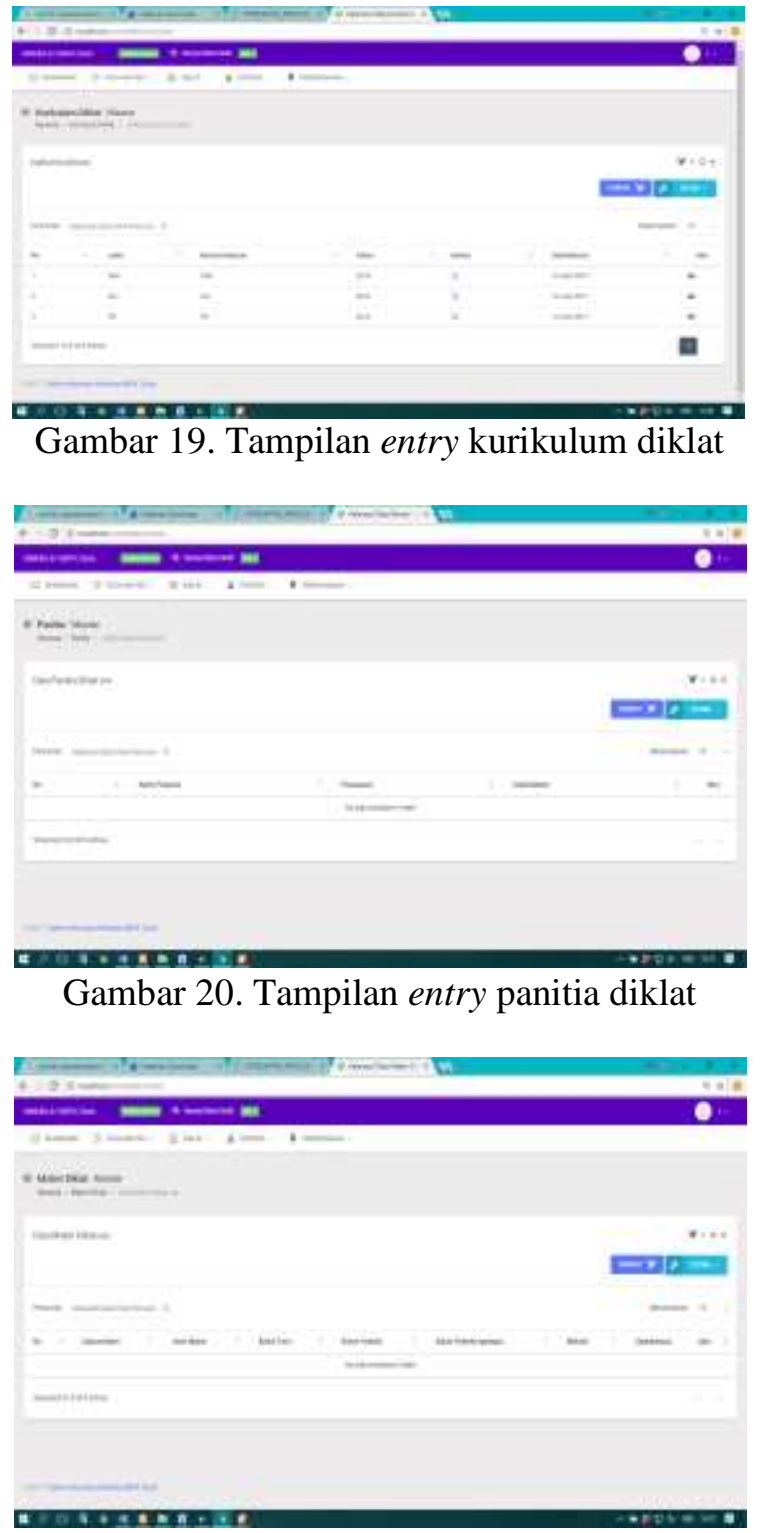

Gambar 21. Tampilan entry materi diklat

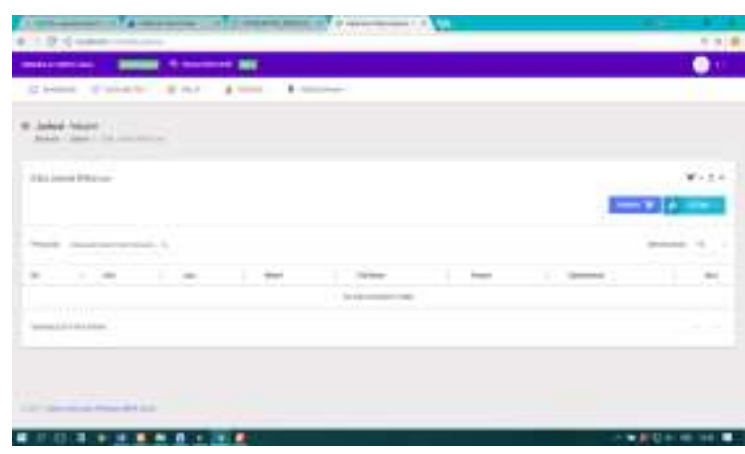

Gambar 22. Tampilan entry jadwal
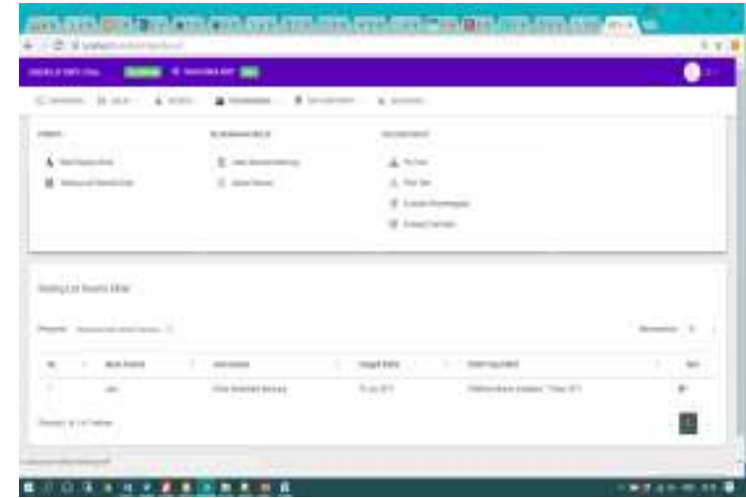

Gambar 23. Tampilan dashboard untuk user pelaksana diklat

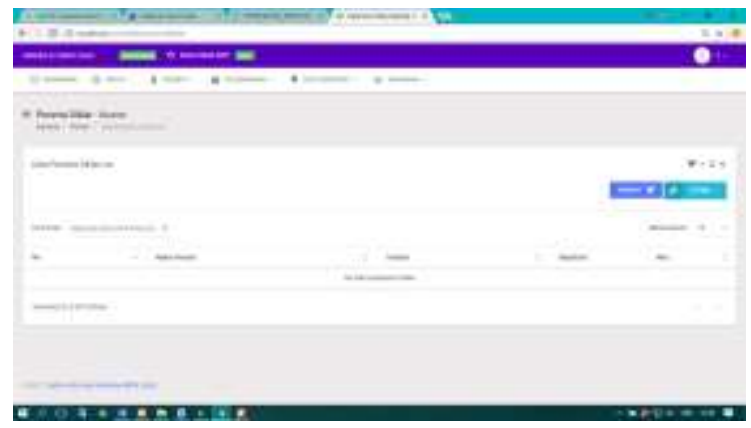

Gamabr 24. Tampilan peserta diklat

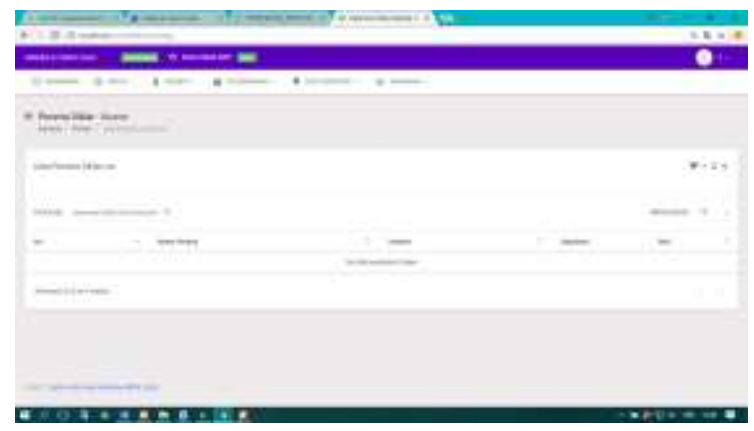

Gambar 25. Tampilan untuk cetak barcode

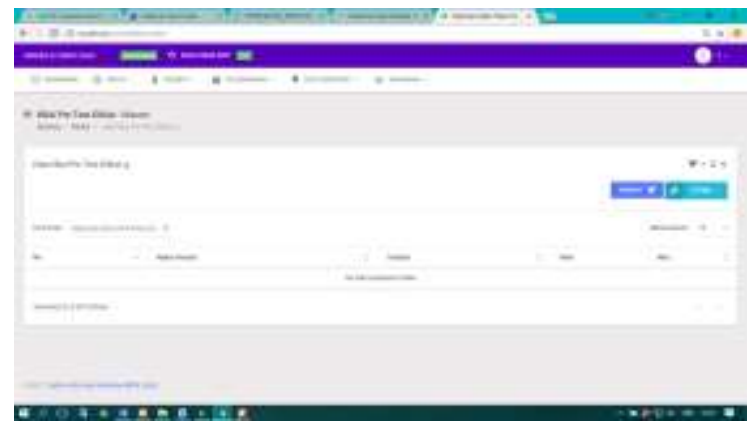

Gambar 26. Tampilan nilai pretest 


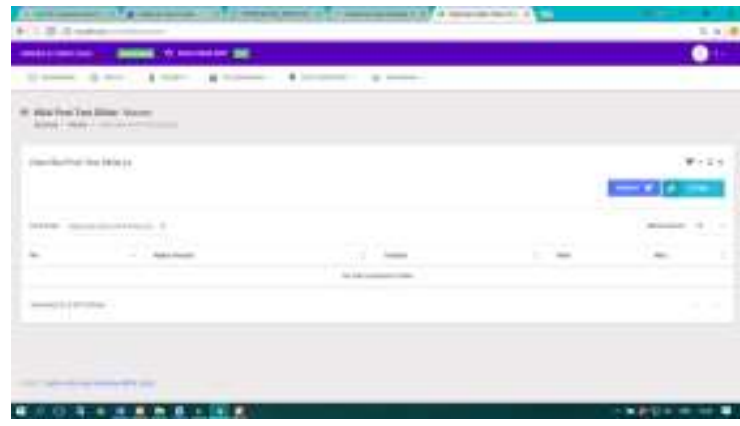

Gambar 27. Tampilan nilai postest
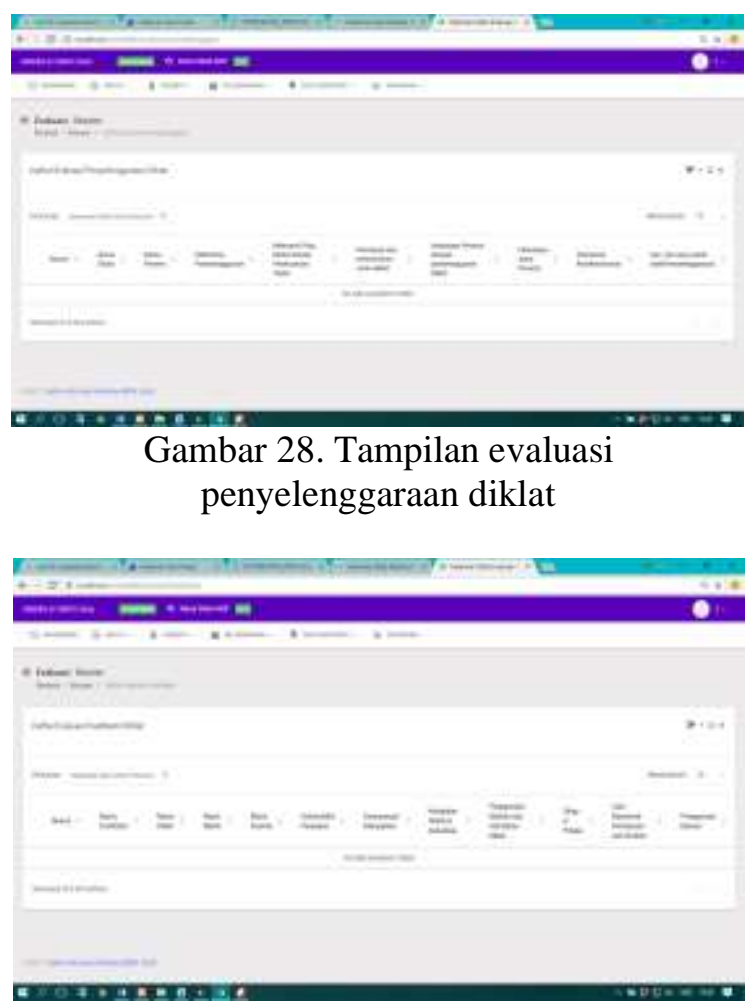

Gambar 28. Tampilan evaluasi fasilitator

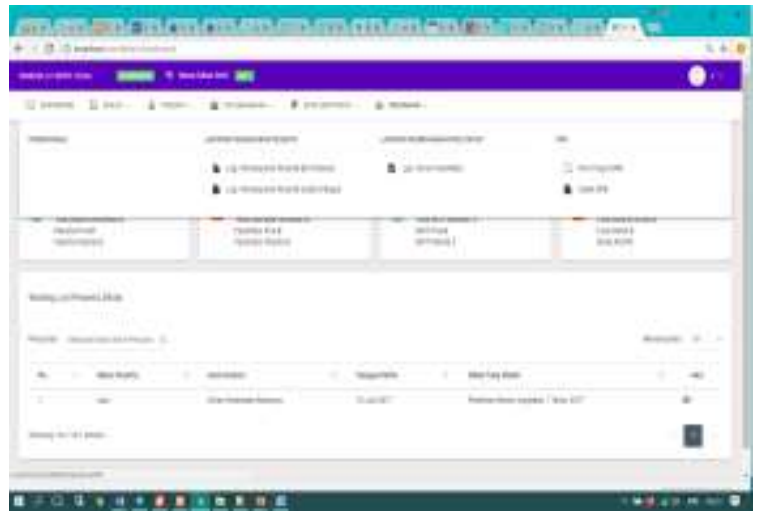

Gambar 29.Tampilan untuk user keuangan

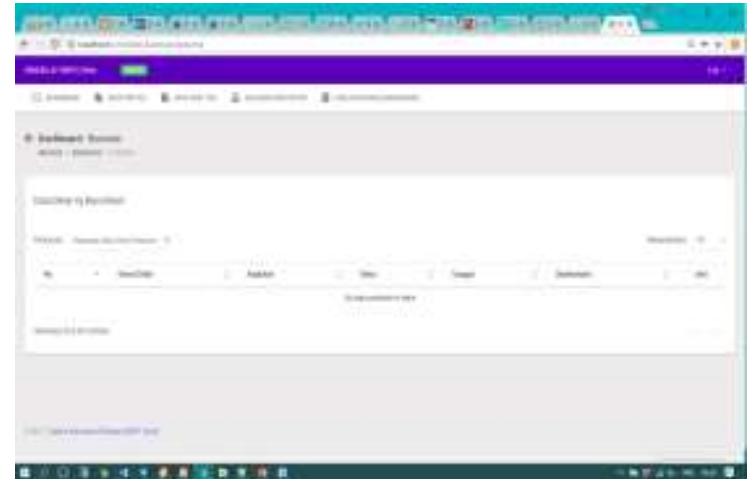

Gambar 30. Tampilan dashboard peserta diklat

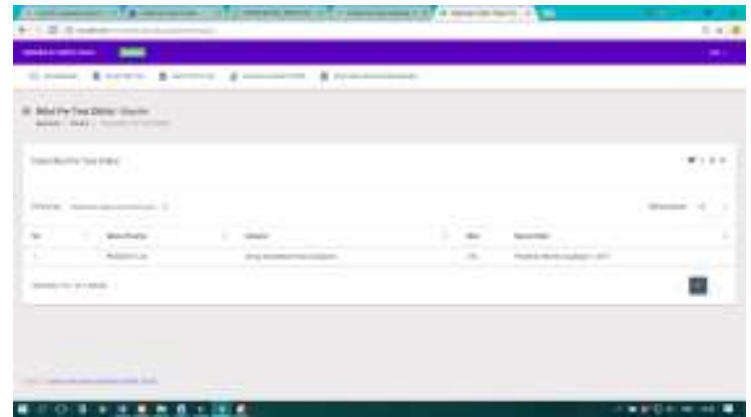

Gambar 31. Tampilan nilai pretest dari sisi peserta diklat

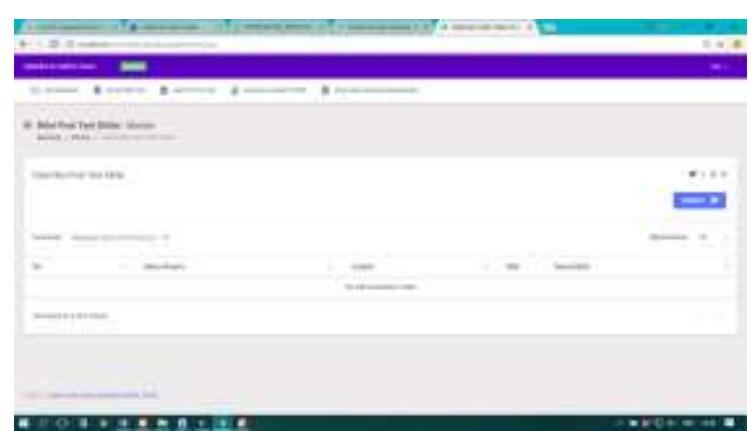

Gambar 32. Tampilan Nilai Postest dari sisi peserta diklat

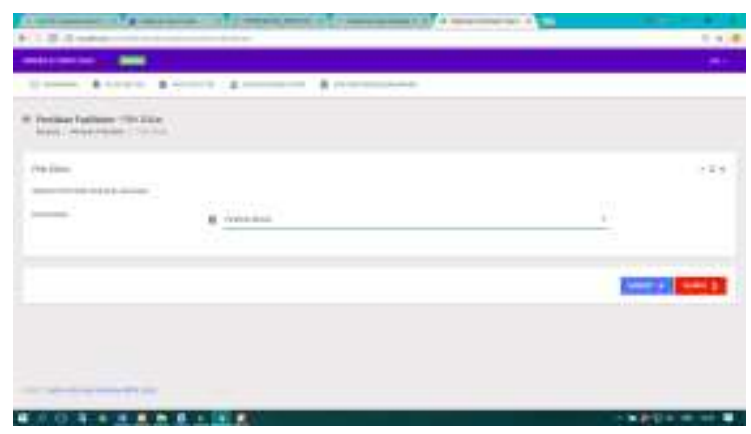

Gambar 33. Tampilan kuesioner penilaian fasilitator 


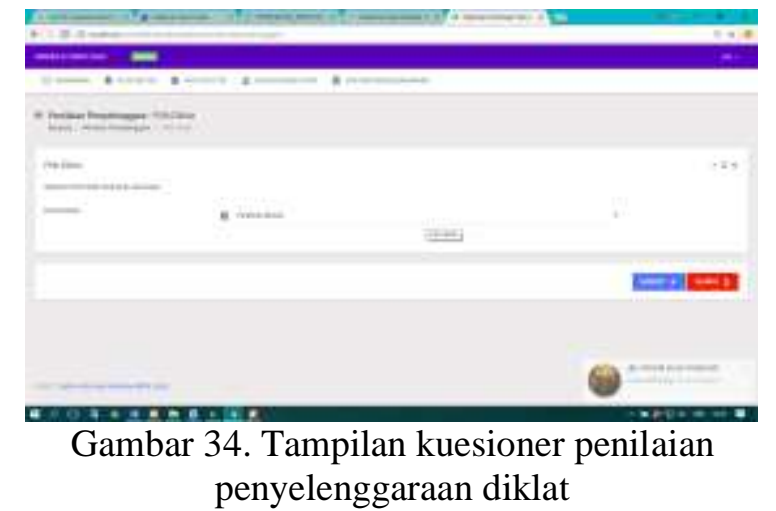

Sistem Informasi Diklat ini user untuk mengakses sistem terbagi menjadi lima dashboard yaitu Administrator ,peserta diklat, bagian perencanaan, bagian pelaksana dan keuangan. Pembagian ini berfungsi agar setiap user hanya mengakses data sesuai tugas dan tanggung jawabnya. Pada Dashboard administrator, user dapat mengakses data master, diklat dan peserta. Data master digunakan untuk mengisi data pangkat, golongan, jabatan, ruang kelas, divisi instansi, fasilitator, MOT dan pegawai internal. Di setiap entri form data master tersebut di fasilitasi dengan fasilitas hapus, edit , pencarian dan cetak.

Menu diklat pada dashboard administrator digunakan untuk menambahkan data pelatihan, dalam form ini pun dilengkap fasilitas sama dengan fasilitas pada menu master.

Sedang menu peserta digunakan untuk menambahkan user pengguna Sistem Informasi Diklat ini.

Dashboard perencanaan terdiri dari menu klasifikasi peserta, jenis diklat, data kurikulum, data panitia, data materi diklat, jadwal pelatihan. Semua menu entry dari perencanaan difasilitasi fasilitas entry, hapus, edit, pencarian dan cetak. Dasboard pelaksana terdiri dari menu data peserta diklat, mencetak barcode peserta diklat, data pretest, data postest, data evaluasi fasilitator, data evaluasi penyelenggaraan.

\section{Pengujian}

Pengujian pada penelitian ini dilakukan dengan menguji Sistem Informasi Diklat ini secara keseluruhan. Pengujian ini dilakukan terhadap semua fungsional yang terdapat pada sistem informasi diklat. Berdasarkan hasil pengujjian fungsionalitas dan penerimaan pengguna yang telah dilakukan , maka hasil yang didapatkan sebagai berikut :

- Seluruh fungsi yang dijalankan pada Sistem Infomasi Diklat dapat diproses dengan baik. Setiap inputan yang dimasukkan dapat diproses dengan baik dan berhasil memberikan output data sesuai yang diharapkan

- Sistem Informasi Diklat BBPK Ciloto ini dapat memenuhi semua fungsi yang dibutuhkan user.

- Sistem Informasi Diklat BBPK Ciloto ini digunakan oleh seluruh penyelenggara diklat, maka untuk itu dibutuhkan suatu pelatihan dan komitmen pimpinan dalam mengimplemnetasikannya.

\section{KESIMPULAN DAN SARAN}

\section{Kesimpulan}

Kesimpulan yang didapat dari pengembangan sistem informasi diklat :

- Sistem Informasi Diklat dapat memfasilitasi komunikasi antar unit kerja di BBPK Ciloto

- Sistem Informasi Diklat ini dapat mendokumentasikan seluruh proses bisnis tentang penyelenggaraan diklat, sehingga memudahkan dalam hal perencanaan, pelaksanaa, evaluasi dan pelaporan

- Sistem Informasi Diklat ini juga menghemat biaya dikarenakan seluruh dokumentasi difasilitasi oleh sistem sehingga more paperless.

\section{Saran}

Di Indonesia balai pelatihan yang dinaungi oleh kementrian kesehatan bukan hanya BBPK Ciloto saja, untuk penelitian selanjut diharapkan dapat mengintegrasikan seluruh balai besar pelatihan kesehatan yang ada di seluruh indonesia.

\section{DAFTAR PUSTAKA}

Andika, D. 2018. Pengertian Flowchart. Retrieved from it-jurnal.com: https://www.it-jurnal.com/pengertianflowchartl 
tutorialspoint.com. (2018, 04 10). CodeIgniter Tutorial. Retrieved from tutorialspoint.com:

Whitten, Jeffery L.; Lonnie D. Bentley. 2004. Systems Analysis and Design Methods. 6 edition. McGraw-Hill

Pressman, R.S. 2015. Rekayasa Perangkat Lunak : pendekatan Praktisi Buku I. Yogyakarta. Andi. 